\title{
Glidant Excipient
}

National Cancer Institute

\section{Source}

National Cancer Institute. Glidant Excipient. NCI Thesaurus. Code C42654.

An inactive ing redient of the pharmaceutical dosage form that is added to promote powder flow during the manufacture of pills. 